\title{
Virginia Doellgast: Disintegrating Democracy at Work: Labor Unions and the Future of Good Jobs in the Service Economy
}

\section{Citation}

Dobbin, Frank. 2013. Virginia Doellgast: Disintegrating Democracy at Work: Labor Unions and the Future of Good Jobs in the Service Economy. Administrative Science Quarterly 58 (1): 152-154.

\section{Published Version}

doi:10.1177/0001839212472661

\section{Permanent link}

http://nrs.harvard.edu/urn-3:HUL.InstRepos:11315410

\section{Terms of Use}

This article was downloaded from Harvard University's DASH repository, and is made available under the terms and conditions applicable to Other Posted Material, as set forth at http:// nrs.harvard.edu/urn-3:HUL.InstRepos:dash.current.terms-of-use\#LAA

\section{Share Your Story}

The Harvard community has made this article openly available.

Please share how this access benefits you. Submit a story.

\section{Accessibility}




\section{Administrative Science Quarterly}

\section{Virginia Doellgast: Disintegrating Democracy at Work: Labor Unions and the Future of Good Jobs in the Service Economy \\ Frank Dobbin}

Administrative Science Quarterly 2013 58: 152 originally published online 18 January 2013

DOI: $10.1177 / 0001839212472661$

The online version of this article can be found at:

http://asq.sagepub.com/content/58/1/152

\section{Published by:}

(\$)SAGE

http://www.sagepublications.com

On behalf of:

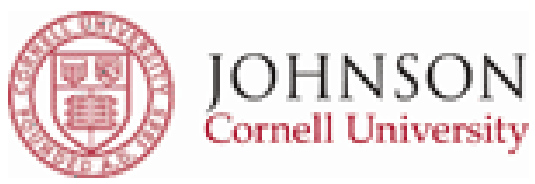

Johnson at Cornell University

Additional services and information for Administrative Science Quarterly can be found at:

Email Alerts: http://asq.sagepub.com/cgi/alerts

Subscriptions: http://asq.sagepub.com/subscriptions

Reprints: http://www.sagepub.com/journalsReprints.nav

Permissions: http://www.sagepub.com/journalsPermissions.nav

>> Version of Record - Feb 8, 2013

OnlineFirst Version of Record - Jan 19, 2013

OnlineFirst Version of Record - Jan 18, 2013

What is This? 
Administrative Science Quarterly

58 (1)152-154

(c) The Author(s) 2013

Reprints and permissions:

sagepub.com/

journalsPermissions.nav

DOI: $10.1177 / 0001839212472661$

asq.sagepub.com

(S) SAGE

Virginia Doellgast: Disintegrating Democracy at Work: Labor Unions and the Future of Good Jobs in the Service Economy. Ithaca, NY: Cornell University Press, 2012. 249 pp. \$65.00, hardcover; \$24.95, paper.

Determined to figure out whether there is any hope for service-sector workers caught in the downward spiral of deskilling, declining wages, deunionization, outsourcing, and job insecurity, Virginia Doellgast examines a workplace that exemplifies these trends, the call center. Her intensive study of matched pairs of call centers in Germany and the U.S., based on observation, archival documents, and some 300 interviews, shows that the situation is bleak, but not quite as bleak as the title, Disintegrating Democracy at Work, might suggest. She concludes by sketching a way forward, toward a utopian world in which call-center workers are self-managed, highly skilled members of strong unions who enjoy job security and high wages. That system can be self-reinforcing, for it saves training and turnover costs, and by ensuring high-quality service, offers firms competitive advantages. The system can still be found in some German and U.S. telecom call centers. Doellgast interviews skilled, high-wage call-center workers in each country who are engaged by their work, are devoted to their unions, and have been in their jobs for a generation. But cost and performance pressures have led firms to chip away at the foundations of these good jobs and to outsource jobs to low-wage, non-union firms in which workers face degrading electronic and supervisory monitoring. Workers, unions, and firms can fight these trends, but the utopia Doellgast imagines seems a long shot.

The road to that utopia is through institutional transformation and reinforcement of existing progressive union and workplace institutions. Doellgast's analyses show the rest of the West how Germany has succeeded in maintaining high wages, stable jobs, and democratic workplaces not only in manufacturing but even in the service sector. By maximizing worker participation and skills, we surmise, call centers enable workers to field more calls, solve problems more effectively through better knowledge of the business, waste less customer time, and give customers a better experience.

In vivid descriptions of the call centers she spent time in, and eye-opening interviews, Doellgast shows us the wide range of experiences call workers have. While call centers may look the same, with cubicles and monitors and headsets, the job varies enormously. When I worked in a call center, I saw the worst: frequent firings; low wages; intense and degrading monitoring by boorish supervisors ("You're being paid to make calls, not to drink coffee"); electronic monitoring of calls made and units sold; and widespread alienation, although antipathy toward the boss brought us together. Doellgast finds places like the one where I worked, but also places where workers are happy with 
their lot. She uses call centers to illustrate all that is wrong with advanced economies, as well as how things can be made right.

Banks, telecommunications companies, and airlines should resist the urge to outsource call center work if they want to improve customer care, lower turnover and training costs, and boost corporate performance. In-house call centers should be unionized, and unions should fight for participatory management, training, and skill enrichment, for these are the things that increase workplace democracy and give high-wage call centers a comparative advantage-skilled workers are more effective messengers, salespeople, and problem-solvers. This is the subtext rather than the text of the book, which is written for labor relations specialists rather than for executives, but the object lesson is clear enough: high-skill, high-participation, high-wage workers are not just happier campers, they are better for business.

Telecommunications in Germany and the United States have come to look more alike thanks to German privatization. Both countries once had telecom monopolies, and now both have competitive markets and price pressure. In the matched-case comparisons of workplaces facing similar pressures, Doellgast finds that in the U.S., unions can rarely resist increased monitoring, decreased autonomy, and deskilling. By contrast, German unions and works councils negotiate to maintain skills and autonomy and encourage participatory work systems. They don't always succeed, but in both countries, where unions succeed in resisting, the best kinds of jobs are sustained.

The degradation of work can occur within workplaces, as competition-driven innovations reduce pay, unionization, autonomy, and worker self-direction. But the worst degradation occurs when employers either outsource or turn over workplaces to new management, spinning off call centers as independent subsidiaries or selling them to contractors. Doellgast champions union power, but she also points out that some successful U.S. organizing campaigns have led firms to outsource to right-to-work states, although this is no reason to shy away from organizing. Executives have bought the argument that job degrading promises to contain costs, despite a lack of good evidence that firms save more money than they lose in turnover and training costs, declines in customer satisfaction, deterioration in sales, and reduction in market share.

Doellgast's survey of call-center work, conducted with an international team, documents that the patterns found in her intensive case studies are representative of the U.S. and Germany more generally. Moreover, broadly similar relationships exist in other countries: work conditions deteriorate under outsourcing; strong unions reinforce high-participation work practices and high wages. National institutional patterns shape the particular outcomes. France experiences less wage inequality across work sites, thanks to a high minimum wage and a collective bargaining system that makes union-negotiated work conditions nearly universal. Denmark's strong unions have fostered high wages and high participation nearly across the board, thanks in part to traditions of skill training and wage compression.

Doellgast remains upbeat about the possibility of positive change in these systems, seeing the building blocks of management-labor collaboration that can contribute to an increase in worker participation, an increase in wages, and ultimately, an increase in global competitiveness for developed countries now competing for jobs with third-world firms. The secret of Germany's highparticipation, high-skill, high-wage manufacturing powerhouses can, it seems, 
be learned by service-sector firms, even those that face real international competition. Whether the answer will be high-participation work systems negotiated by strong unions remains to be seen, but there is another ray of hope on the horizon. In the United States, even non-union firms have seen growth in high-participation work practices. Self-managed work teams, problem-solving teams, cross-training for workers, job rotation, group incentives, and jobsecurity pledges have grown in prevalence in recent decades (Ichniowski, Shaw, and Prennushi, 1997; Kalev, 2009). Perhaps high-participation workplaces will prove their efficacy and become commonplace despite declining union power. That might be the best hope for a Doellgastian utopia in the Far West.

\section{Frank Dobbin}

Department of Sociology

Harvard University

Cambridge, MA 02138

dobbin@fas.harvard.edu

\section{REFERENCES}

Ichniowski, C., K. Shaw, and G. Prennushi

1997 "The effects of human resource management practices on productivity: A study of steel finishing lines." American Economic Review, 87: 291-313.

Kalev, A.

2009 "Cracking the glass cages? Restructuring and ascriptive inequality at work." American Journal of Sociology, 114: 1591-1643. 